\title{
CHILD'S READINESS FOR SCHOOL AS PRIORITY SUBJECT DETERMINANT
}

\author{
Tetiana Pantiuk \\ Drohobych State Pedagogical University named after Ivan Franko, Ukraine \\ Olena Nevmerzhytska \\ Drohobych State Pedagogical University named after Ivan Franko, Ukraine \\ Svitlana Ivakh \\ Drohobych State Pedagogical University named after Ivan Franko, Ukraine \\ Lesia Perkhun \\ Drohobych State Pedagogical University named after Ivan Franko, Ukraine
}

\section{Mariia Yarushak}

Drohobych State Pedagogical University named after Ivan Franko, Ukraine

\begin{abstract}
The article deals with the issue of a child's readiness for school as an important personal determinant and a holistic system of child's individual characteristics. The child's readiness for school has been considered in the research holistically. It involves the development of motivational and cognitive activity, the level of formation of communication mechanisms, analytic-synthetic and volitional activities. Complex characteristics of physiological, mental, motivational and intellectual components of the preschooler's readiness for school have been taken into account. The objective of the article consists in analyzing the child's readiness for organized schooling as an important subjective determinant and justification of the cause-and-effect relationship between preschooler readiness for school and family education. Certain criteria for the six-year-old children's psychophysiological readiness for school in the process of conducting a comprehensive study have been considered. They are as follows: the health group (first or second); the level of physical and motor development in relation to age and sex norms; sensorimotor properties and skills; intellectual development, social maturity. In order to diagnose the child's readiness for school the following methods have been used in the research: an experimental conversation to identify a preschooler's internal position (by T. Nezhnova); school readiness assessment (by Kern's-Yerasek test); the technique of "Graphic Dictation" (by D. Elkonin); the test "Preservation of Quantity" (by J. Piaget); Philippine test etc. Based on the study of parents' involvement in the process of preparing children for school, the conditionality of the child's level of readiness is substantiated by the system of factors, certain conditions of the family in which she was brought up. The study proves that the child's successful transition from pre-school to school is possible on condition that the child has developed appropriate physical, social and mental skills ensuring his/her readiness for school. The integrity of the process of the child's preparation for school and the development of the above mentioned components are the key to the child's further progress and socialization at school.
\end{abstract}


Keywords: preschooler, child's readiness for school, child's preparation for school, school maturity, preschool education, family, school.

\section{Introduction}

The 21-st century identifies and largely corrects traditional trends in social development. There are dominant things nowadays: informatization, globalization, integration, technologicalization, urbanization. It has usually a positive impact on social ontogeny, but often dominates the personality that attempts to cope successfully with the challenges and risks of the modern world. The person should activate additional psychological mechanisms for it. It would enable to feel confident, comfortable, protected, successful. The development of a new person should start from an early age, since the mechanisms and nature of sensitive periods will not give it a second chance in the future, no matter how sophisticated educational technologies might be. All highly developed countries of the world work on such educational tasks.

Defining the responsibility of education for human life and health as one of its priorities, scientists emphasize its new function: “... we must teach the young generation to survive in extreme social and economic conditions, to foster a peculiar culture of existence in the world, in a society that isn't included not only to global "terrestrial" but also to cosmic, world processes" (Frankl, 1990).

Education is characterized by modern scholars as the most conservative component of the modern society life: "At the same time, national educational systems, despite individual initiatives and projects, remain isolated and most rigid elements of modern civilization.... Reforms transform only the material components in this field. The form of education (its content, methods, tools, goals, programs, algorithms etc), without affecting its "human dimension" people involved in educational processes. Educational systems ignore the problems and challenges of a globalizing world" (Rogers, 2002). In this sense, personal educational determinants need to be taken into account not only in the process of constructing the latest educational models, but also education must become personally focused.

We will make an attempt to investigate the essential characteristics of both the process of preparing a child for school in the present environment and its readiness for schooling in the globalized and informative circumstances of society. We argue that the development of a personality is most productive during the preschool childhood. It determines the next vector of human life in our belief.

The aim of our article is to investigate and substantiate the system of preparing the child for school, analyze the child's readiness for organized schooling as an important subject determinant, substantiate of cause and effect 
relationships between the level of readiness of pupil of preschool age and family education.

A number of theoretical and empirical methods were used to achieve this goal: theoretical - analysis (theoretical, terminological) - to determine basic theoretical positions and concepts; abstraction and concretization - for establishing the laws and principles of the process of preparing a child for school and forming the personal readiness of the preschooler; empirical "Educational motivation” by M. Ginsburg (Ginsburg, 1988), “Talk about school” by T. Nezhnova (Nezhnova, 1988); Philippine test (Philippine test, 2003); questionnaire "Profile of social development of a child of six years old" (Pavelkiv \& Tsigipalo, 2013) and methodology "Sequence of events" (Pavelkiv \& Tsigipalo, 2013); Kern-Yerasek test (Yerasek, 1978), "Graphic Dictation" by D.Elkonin (Elkonin, 2010), Quantity Saving test J.Piaget (Piaget, 1969) and surveys of parents; mathematical - for quantitative and qualitative analysis of empirical data.

\section{Theoretical basis of the study}

A significant feature of modern preschool is the fact that global change has affected social life in all its planes and dimensions and in particular they have affected the life of the individual. Modern preschoolers are in a dynamic and rapidly changing environment. They are characterized by high emotional sensitivity, early adaptation to the environment, mental activity, awareness in various spheres of life, change of traditional values, etc. The complex and contradictory perception of the environment requires the individual's special skills and mechanisms to adapt to and function in the world. These processes must begin in early childhood, when the child is open to change and his or her life vector is plastic.

The processes of globalization and integration of the modern world also actualize the personal determinants of pre-school education, expand the space of pre-school education and require changes in the essential and formal dimensions: formation of new content of education; empowering inclusive education; a radical change in the paradigm of Ukrainian education from authoritarianism to humanism and democracy; close attention to the education and development of each individual, taking into account his own life trajectory of development. It is in this sense that pre-school education is of particular importance, as the starting opportunities of the child at the beginning of his / her systemic school education will determine the character of life progress and the corresponding life trajectory (Pantyuk, 2016).

The analysis of the scientific literature (Kosenko, 2016; Krutiy, 2009; Fedorovych, 2003; Cherepanya, 2006) proves that the preparation of children for 
school is a complex process and covers all spheres of life of a preschooler: play, communication, work, socialization, etc. The integrity of this process is that it applies to all areas of the child's life and to all levels of development: social, personal, motivational, volitional, intellectual, physical, and physiological. All of them are necessary for a comfortable stay of the child in school, realization of communication tasks, successful mastering of the school program, preservation and strengthening of her health. In the course of the study, we identified a number of determinants that significantly influence the preparation of the child for school and the formation of appropriate readiness. These include axiological, globalization, economic (material), personal (subjective), institutional, and cultural and educational. Since our scientific exploration is about subjective determinant, we will give a brief description of it in both the social and pedagogical dimensions.

The role and place of the individual in social development are indisputable. Even though a person always acts and depends on social conditions and circumstances, the fact that the role of the individual in the social development is important is still objective. The history of social development shows that it is the personality that can accelerate the progress of social progress, and it can also cause social regression. In particular, science is not a collective creation, it is usually developed by individuals. The same applies to the arts, culture, education and other areas of human life. Therefore, the personal determinant is social in nature (Pantyuk, 2016).

Analysis of education as a social phenomenon indicates the priority role of the individual in it. It is primarily about two subjects of the educational process the child (the student) and the teacher-educator. In all modern educational documents, the child's personality is recognized as individual, unique, so the subjective determinant of preparing a child for school is the priority of a humane, child-centered, personally-oriented education that takes into account the needs, preferences, opportunities, needs and tendencies. We believe that the personal determinant should be the formative basis for the selection of all pedagogical tools for preparing the child for school (Pantyuk, 2016)

It should be noted that modern educators in the system of preparing children for school are noted for interesting and non-standard approaches, focusing on the personal determinant and the importance of individual approach to each child. So, necessary for the formation of the child's readiness for school, scientists consider the principles of emotional satisfaction, problems, understanding of cognitive material and reliance on the past experience of the child, ensuring the unity of activity, emotional and intellectual, priority enrichment of the personal experience of the child, integration, unity of the institution of seven preschool basic quality education (Havrysh, Brezhneva, Kindrat, \& Reypolska, 2015). 
Exactly in the positions of close cooperation between the institution of preschool education and the family on the education of basic qualities in the context of preparing the child for schooling, foreign scholars also emphasize. They emphasize the importance of this stage in the "development of each child and their family", because they believe that "... transition to school is marked by stressful situations for the future student, the guarantee of which can be eliminated as closely as possible by all participants in the educational process, because for the special support during this period the child expects from his closest people - from father and mother" (Marzec \& Borda, 2016; Niesel \& Griebel, 2017).

However, the most valuable in the scientific position of scientists, in our opinion, is the child-centered approach, the interpretation of the child subject of the educational process: "The process of understanding and appropriation of the child intellectual, cultural, spiritual values of mankind does not occur mechanically by the formula: "educator gives - the child bearer. In order to avoid "impoverishment of the soul when enriching information" (O. Leontiev's statement), it is necessary for the child to be a subject of activity, in particular, of the process of cognition" (Havrysh et al., 2015).

Important in the process of preparing a child for school is the harmony and balance between education, upbringing and development, which we consider the equilibrium and necessary components of the personality formation process. The diminishing role of any of them is detrimental to the child: "It is clear that the educational process can be comprehensively effective only on condition of its integrity, only in the unity of its educational and developmental functions, since the personality itself is one and indivisible. Any attempt to artificially dismember this integrity, to exert a separate educational, educational or developmental influence on certain qualities of a person is pre-eminently condemned, after all, leading to a violation of harmony, absolutely unacceptable distortions in the world view and world outlook" (Skotnyj, 2004).

Our study also proves that the transfer of the share development and upbringing to education and assimilation of a large amount of information, which is often not subject to systematization in view of the small experience of a preschool child, threatens not only the loss of interest in learning, but also significantly impairs health.

\section{Methodology and Results}

Investigation objective and tasks taken into consideration, the experimental research of children' preparedness level for study at school based on three preschool educational establishments (PEE) in the city of Drohobych, Lviv region (PEE № 11 "Svitlyachok", PEE № 13 "Kazka" and PEE № 24 
"Smerichka") was carried out. 150 children of the senior preschool age were involved in the experiment. The experimental study was performed in October through December, 2019.

At the preliminary stage, evaluation criteria system of a child's preparedness for school, as well as diagnostic methods complex were selected. Particular attention was paid to the methodological work and cooperation of the pedagogical staff and parents, who participated in the experiment. The issues of the child getting ready for school were discussed at the methodological councils, creative teams' meetings, parents' evenings, general activities being coordinated.

The experimental work objective and its core were brought to the attention of the preschool pedagogical staff involved in details. Group studies were carried out according to typical requirements. The outcomes accounting and processing were recorded in the study protocols, containing the results of teaching and educational process. The observation data were compared with the established standards, thus enabling to estimate deviations from the norm. Regular monitoring of each pre-schooler and group development dynamics was provided. The findings obtained were summarized in tables and diagrams to compare development effectiveness of individual children and experimental groups on the whole.

The methods used were determined by the research objective and inextricably linked in terms of teaching process content and specifics. When choosing methods, its actual effectiveness as well as validity of results for characterizing the parameter under study, were considered. Thus, a child's experimental outcomes were mutually complementary, so providing a comprehensive picture of preparedness for school in the respect of motivation, physical, social, and psychological preparedness.

In order to evaluate the level of a child's motivation preparedness for school, we used methodology "Motivation for study" by M. Ginsburg (Ginsburg, 1988) and "Discussion on the school" by T. Niezhnova (Niezhnova, 1988). The results made it possible to find out an interest for school study in senior preschool children and revealed the specifics of a schoolchild's intrinsic position. The following criteria were used: a child's wish for going to school, based on the adequate notion about it; positive attitude towards study; willingness for communication. According to the results of these methods, $7.2 \%$ of respondents have a high level of motivational readiness to study at school, an average of $40.5 \%$ and a low of $52.3 \%$.

To estimate the levels of a child's physical fitness for school, we used oriented graphic A test by (Yerasek, 1978) and Philippine test (Philippine test, 2003), which provided data about the development of fine arm/hand motor function and visual motor coordination, as well as information on the body 
proportions (head, trunk, limbs) and growth rate (half-growth jump) of every child. The accepted physical fitness criteria were excellent health status, proper coordination, free spatial orientation, correct posture, "muscle strength - age" compliance, and preparedness of the hand for writing. The application of this methodology made it possible to find out: $7.4 \%$ of children with high level of physical readiness for school education, $41.8 \%$ with average level and 50.8\% with low level.

When determining the level of a child's social preparedness for school, we used a questionnaire "Profile of 6-year old child development" (Pavelkiv \& Tsigipalo, 2013) and methodology "Sequence of events" (Pavelkiv \& Tsigipalo, 2013). Based on them, we found whether senior preschool children reveal a need for communication with their age-mates, readiness to submit to group interests and rules, dialogue skills, as well as ability to compose stories on the known subject, to communicate differently with teachers, parents, and age-mates. Accordingly, a child's ability to apprehend, preserve and recreate information, as well as skills in establishing relations with age-mates and grownups were considered to be the indicators of social preparedness. The results obtained by these methods were as follows: $6 \%$ of preschoolers have a high level of social activity for schooling, $42.6 \%$ have an average, and $53.4 \%$ have a low one.

It should be noted that levels of intellectual development as the basis of child's psychological readiness for schooling were determined using KernYerasek test (Yerasek, 1978); method of D. Elkonin "Graphic Dictation" (Elkonin, 2010); Jean Piaget's test “Conservation of number” (Piaget, 1969). It made possible to obtain information about the development of spontaneous regulation of elder preschoolers activity, formation of their thinking function, development of observation, perception, memory, attention, speech, etc. Elder preschoolers were distinguished by differentiation (perceptive maturity), spontaneous concentration of attention, analytical thinking (the ability to understand essential features and interconnections between phenomena), rational approach to reality (the comparative decrease of imagination importance), logic memorizing, some abilities and skills of sound analysis of words, preparation of hand for writing (definite development of fine motor function of the hand and visual motor coordination). According to the determined stages of elder preschoolers, cognition they were ranked as high, average or low levels of intellectual development. Our study found that $8.4 \%$ of pre-school children, $38.4 \%$ with average and $55.2 \%$ with low level of intellectual readiness at school.

It should be noted that elder preschoolers were examined thoroughly as for their readiness for schooling. Detailed findings of examination were noted in individual notebook and special forms for each child. Individual examination was performed by two teachers at once. The child's answers, results of performed tasks were noted by one of the teachers, while the other concentrated 
attention on preschooler's behaviour. Joint action assisted in assessment of child progress.

All indices were summarized by given algorithm above, and give rise to determine the levels of children readiness for schooling (see table below).

Table 1 Indices of children's readiness for schooling

\begin{tabular}{|l|c|c|c|}
\hline Components of readiness & $\begin{array}{c}\text { High level } \\
\text { (\%) }\end{array}$ & $\begin{array}{c}\text { Average level } \\
\text { (\%) }\end{array}$ & $\begin{array}{c}\text { Low level } \\
\text { (\%) }\end{array}$ \\
\hline Motivational & 7,2 & 40,5 & 52,3 \\
\hline Physical & 7,4 & 41,8 & 50,8 \\
\hline Social & 6,0 & 42,6 & 53,4 \\
\hline Intellectual (mental) & 8,4 & 38,4 & 55,2 \\
\hline General index & 10,8 & 42,2 & 49,7 \\
\hline
\end{tabular}

Analysis of the results of confirmation experiment showed that at the end of 6 age-period not all children achieved the level of readiness and did not get the opportunity for systematic successful study at school. Poor development of speech; formal, unconscious usage of different notions and words; underdevelopment of fine motor function; insufficient development of spontaneous memory and attention; unformed skills for self-control development, etc. were not achieved.

This experiment proved the formation of necessary psychic features, new growth and volume of knowledge and skills for some kinds of activities that are determined for this group of preschoolers. Average and low levels dominated in the assessment of readiness for schooling in most children of experimental group.

Thus, the results of confirmation experiment based on general indices, revealed insufficient readiness level of elder preschoolers, that proved nonefficient training of children. Overwhelming majority of children participating in the experiment showed low or average levels of the assigned personal new growth. Low results were observed for such components as "social readiness", "physical readiness", and "motivational readiness".

We consider that the most significant influence on a child's readiness for school has an atmosphere of family upbringing, the absence of conflicts in it, its values, and the status of the child in it. So, in order to study the problem of preparing children for school, we conducted a survey of parents. Based on the analysis of its results, we have learned the parents' attitude to the process of preparing children for school, understanding its importance, their role and responsibility for its effectiveness.

Thus, the parental survey showed the following results. Among 220 surveyed parents who answered the questionnaire, $54.5 \%$ believe that 
children go to school reluctantly or without much desire. $45.5 \%$ of parents believe that the child is not yet ready for school. $77.3 \%$ of parents confirm that children experience their successes and failures emotionally; $22.7 \%$ cannot answer this question. It was found that children quite often share their impressions with their parents about the classes held at the institution of preschool education - this was admitted by $63.6 \%$ of parents. Mostly, the negative and positive impressions are almost equal $-45.5 \%$. Parents claim that children willingly complete the proposed tasks at home $-31.8 \%$.

The experience of working with parents, our observations, conversations with tutors made it possible to classify parents on the basis of their attitude to the preparation of the child for school. So, to the first group we have attributed parents who monitor this issue in mass media and scientific literature, ask for advice the employees of the preschool education institution (tutors, psychologist), willingly respond to proposals of cooperation and implement recommendations; to the second group we have attributed parents who are not indifferent to the process of preparation of the child for school, they often follow the recommendations of the educators, but do not show activity and interest in this process; to the third - we have attributed the parents who are quite passive in this process and put all responsibility for its quality on the pedagogical staff of the institution of pre-school education.

As a result of comparing our diagnosed levels of children's readiness for schooling and their parents' belonging to one of the above mentioned groups, we can state that there is a close causal relationship between the level of child preparation for school and the system of factors determined by the family conditions in which the child was brought up.

\section{Conclusions}

Having summarized the theoretical and applied experience of preparing children for school, taking into account the subjective determinants in the context of the presence, we can identify the priority directions for organizing this process: close interaction of family, domestic environment, pre-school educational institution and school; recognition of the child as the subject of the educational process; formation of communicative skills, stimulation of cognitive activity; care for physical and mental health; improvment of the network of institutions for preparing children for school, modernization of the educational space; development of individually oriented programs for school preparation; training teachers to meet the demands of technologically advanced, globalized world.

Another of its component are naturally defined in the light of the complex vision of the problem of preparing a child for school - pedagogical education 
and culture of parents. Unfortunately, it is often marked by incompetence and inconsistency of educational influences; excessive authoritarism, lack of proper family communication etc. In view of it, the pedagogical education of parents and their active participation in the children education requires the interaction of the pedagogical community and prudent common approaches. It would provide an adequate level of pedagogical knowledge and competence of parents. The prospects for further research are considered in this context.

\section{References}

Cherepania, N. (2006). Orhanizatsiino-pedahohichni umovy pidhotovky ditei do shkoly: avtoref. dys. na zdobuttia nauk. stupenia kand. ped. nauk. Odesa.

Fedorovych, L. (2003). Pidhotovka ditei do shkoly $v$ umovakh navchalno-vykhovnoho kompleksu: avtoref. dys. na zdobuttia nauk. stup. kand. ped. nauk. Kryvyi Rih.

Filipinskyj test. (2003). In Maksymenko, S., Maksymenko, K., \& Glavnyk, O. (Eds.),. Gotovnist dytyny do navchannya (p. 10). Kyyiv: Mikros-SVS.

Frankl, V. (1990). Chelovek v poiskah smysla: sbornik / per. s angl. i nem. D.A. Leont'eva, M.P. Papusha, E.V. Jejdmana. Moskva: Progress.

Elkonyn, D. (2010). Nekotorye voprosy diagnostyky psyxycheskogo razvitiya detej: diagnostika uchebnoj deyatelnosti i intellektualnogo razvytiya detej. M.: Pedagogyka, yzdanye 2-estereotypnoe.

Gavrysh, N., Bryezhnyeva, O., Kindrat, I., \& Rejpolska, O. (2015). Rozumne vyxovannya suchasnyx doshkilnyat : metodychnyj posibnyk. Kyyiv : Slovo.

Gynzburg, M. (1988). Razvytye motyvov uchenyya u detej 6-7 let. Moskva: Pedagogyka.

Havrysh, N. (2002). Rozvytok movlennyevotvorchoyi diyalnosti v doshkilnomu dytynstvi: dys. d-ra ped. nauk. Kyyiv: Nacionalnyj pedahohichnyj universytet imeni M.P. Drahomanova.

Havrysh, N. (2006). Dity i sotsium: osoblyvosti sotsializatsii ditei doshkilnoho ta molodshoho shkilnoho viku. Luhansk: Alma-Mater.

Jyrasek, Ya. (1978). Dyagnostyka shkolnoj zrelosty. Dyagnostyka psyxycheskogo razvytyya. Praga.

Kosenko, Yu. (2016). Suchasni pohliady na problemu nastupnosti doshkilnoi i pochatkovoi osvity. Aktualni problemy nauky ta osvity: zb. nauk.-prakt. konf. vykladachiv MDU. Mariupol: MDU.

Krutii, K. (2009). Osvitnii prostir doshkilnoho navchalnoho zakladu: u 2-kh ch. Zaporizhzhia: TOV «LIPS» LTD.

Marzec, B., \& Borda, M. (2016). Partnerska wspótpraca przedszkola z rodzicami w wynikach ewaluacji zewnętrznej. Biblioteka Współczesnej Myśli Pedagogicznej. Kraków, T.V.

Nezhnova, T. (1988). Dynamika «vnutrennej pozycyy» pry perexode ot doshkolnogo k mladshemu shkolnomu vozrastu. Vesti Moskovskogo universiteta. Seriya 14. Psyxologiya, 1.

Niesel, R., \& Griebel, W. (2017). Transitionen zwischen Familie, KiTa und Schule. Zur Bewältigung von Übergängen zwischen Familie und Bildungseinrichtungen und zwischen den Bildungseinrichtungen.

Pavelkiv, D., \& Tsigipalo, O. (2013). Psyxodiagnostychnyj instrumentarij v umovax doshkilnogo zakladu: navch. posib. Kyiv: Centr uchbovoyi literatury. 
SOCIETY. INTEGRATION. EDUCATION

Proceedings of the International Scientific Conference. Volume III, May $22^{\text {th }}-23^{\text {th }}, 2020.710-720$

Pantiuk, T. (2014). Formuvannia psykholohichnoi hotovnosti dytyny do shkilnoho navchannia. Zbiór raportów naukowych «Wspoółczesne tendencje w nauce i edukacji», $15-18$.

Pantiuk, T. (2016). Pidhotovka ditei do shkoly v Ukraini: suspilno-pedahohichnyi kontekst. Drohobych: Red.-vyd. viddil DDPU im. I. Franka.

Pantiuk, T., \& Ivakh, S. (2011). Metodyka spivpratsi doshkilnykh zakladiv z rodynamy. Drohobych: Red.-vyd. viddil DDPU im. I. Franka.

Piaget, J. (1969). Izbrannye psihologicheskie trudy. M.: Prosveshhenie.

Rodzhers, K., \& Frejberg, D. (2002). Svoboda uchit'sja. Moskva: Smysl.

Skotnyj, V. (2004). Filosofiya osvity: ekzystenciya irracionalnogo $v$ racionalnomu. Drogobych: Vymir. 